Research Letter

\title{
Behavioral reactions of white male rats under stress conditions during the persistent irradiation of THz-band electromagnetic waves of nitrogen oxide occurrence
}

\author{
Vyacheslav F. Kirichuk, Olga N. Antipova, Jana A. Krylova, Evgeny V. Andronov
}

Saratov State Medical University n.a. V.I. Razumovsky, Saratov, Russia

Received 14 December 2012, Revised 25 December 2012, Accepted 20 January 2013.

(C) 2012, Kirichuk V.F., Antipova O.N., Krylova J.A., Andronov E.V.

(C) 2012, Russian Open Medical Journal

Abstract: There had been carried out a comparative analysis of terahertz (THz) radiation exposure of 150.176-150.664 GHz nitrogen oxide occurrences on stress-dependent changes in behavioral reactions of white rats under hypokinetic stress condition. It was found that the radiation fully or partially normalizes behavioral reactions of white male rats under hypokinetic stress condition. The most effective method is persistent 30-minute irradiation.

Keywords: behavioral reactions, stress, THz-band

Cite as Kirichuk VF, Antipova ON, Krylova JA, Andronov EV. Behavioral reactions of white male rats under stress conditions during the persistent irradiation of THz-band electromagnetic waves of nitrogen oxide occurrence. Russian Open Medical Journal 2013; 2: 0103.

Correspondence to Prof. Vyacheslav F. Kirichuk. Address: Department of normal physiology n.a. I.A. Chuevsky, Saratov State Medical University n.a. V.I. Razumovsky, 112, Bolshaya Kazachiya str., Saratov, 410012, Russia. E-mail: normalf@yandex.ru

\section{Introduction}

Human and animals are constantly under different stresses emotional, algetic, hypokinetic, temperature, etc [1]. In hypokinesia there are disorders of all organs and organism systems [2,3]. It is revealed that hypokinesia in animals is marked by: a considerable increase of sympathoadrenal system (SAS) activity, nonspecific resistance and immunoreactivity decrease, behavioral reactions changes. All of these factors point on stress reaction development.

Over the last years there a new kind of informationwave therapy has appeared - terahertz $(\mathrm{THz})$ therapy. The terahertz therapy is performed by terahertz waves of molecular and absorption spectrum occurrence (MASO) of nitrogen oxide - a universal intermediate in different functions of the organism [4]. It has antistress effect [5]. One of the new hypodynamia and hemostasis system drug-free methods of treatment is also a lowintensity irradiance of ultramicrowaves frequency spectrum [6-9]. The survey results of action of the $\mathrm{THz}$ radiation exposure of 150.176-150.664 GHz nitrogen oxide occurrences and $129.0 \mathrm{GHz}$ atmospheric oxygen indicate positive energetic exposure of the given frequencies on blood rheological properties and thrombocytes functional activity [10, 11], fibrinolytic activity and clotting [12], blood gas and electrolytes [13], lipid peroxidation process and blood antioxidant characteristics $[14,15]$, thyroidea condition [16], main indices of metabolism [17], corticosterone concentration in blood [18], blood corpuscle receptor system [19], endothelium condition [20] and microcirculation [21].

This study aimed the comparative analysis of different time modes of $\mathrm{THz}$ radiation exposure of $150.176-150.664 \mathrm{GHz}$ nitrogen oxide occurrences on stress-dependent changes in behavioral reactions of white rats under acute stress.

\section{Methods}

To achieve the goal there have been studied behavioral reactions of 75 white male rats (180-220 g). Hypokinetic stress has been used as a model of stress, which was simulated by taking the animals into individual cages for 3 hours [22].

Five groups of white male rats had been studied. Each of the groups had 15 males: the $1^{\text {st }}$ control group - intact male rats; the $2^{\text {nd }}$ group - a comparative group containing of rats under hypokinetic stress condition; the $3^{\text {rd }}, 4^{\text {th }}, 5^{\text {th }}$ groups - trial groups in which rats had been under persistent $\mathrm{THz}$ radiation exposure of 150.176-150.664 GHz nitrogen oxide occurrences during 5, 15 and 30 minutes respectively.

The following tests had been chosen for the research: "Open field test", "Elevated plus maze", "Dark-light camera".

The "Open field test" had been lasted for 5 minutes. The following indices had been used during the research: the number of crossed squares (horizontal motion activity), standings upright (vertical motion activity) and the number of examined "holes" (exploratory activity). Nonspecific behavioral reactions had been registered separately: the number of defecation boluses, coitus frequencies and grooming overall length (in seconds) (Table 1).

The following behavioral indices had been used in the "Elevated plus maze" test: the number of escapes the labyrinth tubes (exploratory activity), standings upright (vertical motion activity), looking down from the ends of the locked tubes ("risk assessment"), and crossing the central part of the labyrinth. The test had been lasting 5 minutes (Table 2).

The "Dark-light camera" test lasted 5 minutes. The following behavioral indices of the animals activity had been used in the test: looking out from the dark box of the camera to the light one through the hole in the partition, the walking in to the light box, 
the number of peeking-out acts and walking in to the light part of the camera and the length of these activities (in seconds). The intensity of defecation was the index of the nonspecific behavior the number of boluses which had been found after the test in the dark box (Table 3).

Radiation of the animals was performed by a small-sized generator "KVCh-NO-Orbita" \{transliteration from Russian\}. It was developed by Moscow scientists in cooperation with Saratov scientists [23]. The generator worked on MASO of 150.176$150.664 \mathrm{GHz}$ nitrogen oxide. $3 \mathrm{~cm}^{2}$ skin areas above the metasternum had been irradiated. Irradiator had been located $1.5 \mathrm{~cm}$ above the body of an animal.

The researches had been performed according to Geneva Convention "International Guiding Principles for Biomedical Research Involving Animals" (Geneva, 1990). Statistical analysis of the results had been done with the help of nonparametric analysis with Mann-Whitney T-test detection (Statistica 6.0 soft).

\section{Results}

We can see that hypokinetic stress causes the clear stress reaction development, which becomes evident in behavior changes: an increasing of anxiety characterizes statistically-valid decrease of horizontal and vertical motion activity $(p<0.05)$, and exploratory activity $(p<0.05)$ comparing with the control group (Tables 1, 2 and 3). The "Open field test" demonstrates us the statistically-valid decrease of the number of crossed squares, standing upright, examining the "holes", and the changes of a nonspecific behavior of the animals: statistically-valid decrease of defecations comparing with the check group of the rats. This means high anxiety level of the animals (Table 1). In the "Elevated plus maze" test the reduction of the number of the central platform crossings, walking into the open tubes of the labyrinth, standing upright and looking down from the ends of the open tubes (comparing with the check group) demonstrate the reduction of the motion and exploratory activity of the stressed animals (Table 2). In the "Dark-light camera" test there is statistically-valid $(p<0.05)$ decrease of walking out and looking out of the dark part of the camera into the light one (comparing with the check group) (Table 3 ). The decrease of defecations is a nonspecific marker of the stress reaction. So, we can see that the hypokinetic stress causes evident changes in behavioral reactions of white rats.

The researching revealed the dissimilar influence of the different time modes of the persistent irradiation of $\mathrm{THz}$-band electromagnetic waves of $150.176-150.664 \mathrm{GHz}$ nitrogen oxide occurrence on white male-rats under stress. So during the 5minute persistent irradiation of the stressed animals, there had not been fixed any changes in motion and exploratory activity during the "Open field test", "Elevated plus maze", "Dark-light camera" (comparing with the stress group). The number of the crossed squares, standing upright and looking into the "holes" in the "Open field test" (Table 1); the number of the central platform crossings, walking into the open tubes of the labyrinth, standing upright and looking down from the ends of the open tubes in the "Elevated plus maze" test (Table 2); and the number of walking out and looking out of the dark part of the camera into the light one in the hypokinetic stress at the animals from the experimental group statistically-valid ( $p>0.05$ ) does not differ from the animals under the hypokinetic stress (Table 3). This demonstrates low efficiency of the given irradiation mode in preventing of the behavioral reactions disorders at white male-rats.
The 15-minute persistent irradiation of $\mathrm{THz}$-band electromagnetic waves of $150.176-150.664 \mathrm{GHz}$ nitrogen oxide occurrence on white male-rats under the hypokinetic stress influences on behavioral reactions of the animals. So the partial recovery of the indices of behavioral reactions of the animals takes place. In the "Open field test" the horizontal motion activity increases, which is statistically-valid characterized by the number of crossed squares, and statistically-valid $(p<0.05)$ differs from the check group as well as from the stressed group. This may be considered as the tendency to the disordered motion activity recovery (Table 1). In the "Elevated plus maze" test the number of standings upright had been statistically-valid $(p<0.05)$ increased comparing with the stress group and did not differ from the check group, which displays the efficiency of the 15-minute persistent irradiation on the vertical motion activity of the animals (Table 2). The length of the walking out from the dark box to the light one in the "Dark-light camera" test statistically-valid does not differ from the check group (Table 3), while the length of the walking out acts from the dark box to the light one in the stressed group of animals after the 15-minute persistent irradiation of $\mathrm{THz}$-band electromagnetic waves of $150.176-150.664 \mathrm{GHz}$ nitrogen oxide occurrence. This means that the 15-minute persistent irradiation of THz-band electromagnetic waves of $150.176-150.664 \mathrm{GHz}$ nitrogen oxide occurrence is effective in relation to some indices of motion and exploratory activity, which were disordered by the hypokinetic stress.

The 30-minute persistent irradiation of THz-band electromagnetic waves of $150.176-150.664 \mathrm{GHz}$ nitrogen oxide occurrence exerts corrigent influence on the stressed animals behavior. So it takes place the recovery of the motion and exploratory activity in animal behavioral reactions in: the "Open field test", the "Elevated plus maze" test and the "Dark-light camera" test (comparing with the stress group). The indices in the group of the animals under the stress and the THz-band statistically-valid do not differ from the check group (Tables 1, 2 and 3): the number of the crossed squares, standings upright, looking into the "holes" in the "Open field test", the number of the central platform crossings, entrances into the open tubes of the labyrinth, looking down from the open tubes and standings upright in the "Elevated plus maze" test, also the number and the length of the walking and peeking out from the dark box of the camera to the light one in the "Dark-light camera" test. This displays high efficiency of the given time mode of the irradiation in correcting the disorders caused by hypokinetic stress at white male-rats behavioral reactions.

\section{Conclusion}

According to all the results of this study, we can make the following conclusions: 1) the 5-minute persistent irradiation of electromagnetic waves of the given occurrence does not prevent acute stress changes in horizontal and vertical motion and exploratory activity at male-rats; 2) the 15-minute persistent irradiation of THz-band electromagnetic waves of 150.176-150.664 $\mathrm{GHz}$ nitrogen oxide occurrence caused just partial recovery of the behavioral reactions indices; 3) the 30-minute persistent irradiation of THz-band electromagnetic waves of 150.176-150.664 $\mathrm{GHz}$ nitrogen oxide occurrence is effective and totally prevents stress disorders of horizontal and vertical motion and exploratory activity at male-rats.

Conflict of interest: none declared. 
Table 1. Efficiency of the THz-band on MASO of 150.176-150.664 GHz nitrogen oxide occurrence on indices in behavioral reactions changed by the hypokinetic stress at white male-rats (in the "Open field" method)

\begin{tabular}{|c|c|c|c|c|c|}
\hline \multirow{2}{*}{ Indices $\quad$ Groups } & \multirow{2}{*}{$\begin{array}{l}\text { Check } \\
(n=15)\end{array}$} & \multirow{2}{*}{$\begin{array}{l}\text { Hypokinetic stress } \\
(n=15)\end{array}$} & \multicolumn{3}{|c|}{ Stress combined with persistent irradiation $(\mathrm{n}=15)$} \\
\hline & & & 5 minutes & 15 minutes & 30 minutes \\
\hline The number of the & $38(29,49)$ & $17(13,20)$ & $18(13,21)$ & $23(19,28)$ & $36(28,41)$ \\
\hline crossed squares & & $\mathrm{p}_{1}<0.001$ & $\mathrm{p}_{1}<0.001, \mathrm{p}_{2}=0.494$ & $p_{1}<0.001, p_{2}=0.007$ & $\mathrm{p}_{1}=0.709, \mathrm{p}_{2}<0.001$ \\
\hline \multirow[t]{2}{*}{ Standing upright } & $16(13,20)$ & $10(5,13)$ & $10(6,14)$ & $12(8,15)$ & $16(14,20)$ \\
\hline & & $\mathrm{p}_{1}<0.001$ & $\mathrm{p}_{1}<0.001, \mathrm{p}_{2}=0.724$ & $\mathrm{p}_{1}=0.013, \mathrm{p}_{2}=0.184$ & $p_{1}=0.693, p_{2}<0.001$ \\
\hline \multirow{2}{*}{$\begin{array}{l}\text { The number of } \\
\text { defecations }\end{array}$} & $1(0,2)$ & $2(1,4)$ & $2(1,4)$ & $2(0,3)$ & $1(0,1)$ \\
\hline & & $\mathrm{p}_{1}=0.011$ & $\mathrm{p}_{1}=0.279, \mathrm{p}_{2}=0.604$ & $\mathrm{p}_{1}=0.158, \mathrm{p}_{2}=0.184$ & $\mathrm{p}_{1}=0.787, \mathrm{p}_{2}=0.009$ \\
\hline \multirow{2}{*}{$\begin{array}{l}\text { Grooming (the number } \\
\text { of acts) }\end{array}$} & $3(2,4)$ & $0(0,1)$ & $0(0,1)$ & $1(0,1)$ & $3(2,4)$ \\
\hline & & $p_{1}<0.001$ & $\mathrm{p}_{1}<0.001, \mathrm{p}_{2}=0.534$ & $\mathrm{p}_{1}<0.001, \mathrm{p}_{2}=0.085$ & $p_{1}=0.709, p_{2}<0.001$ \\
\hline \multirow[t]{2}{*}{ Grooming (in seconds) } & $21(10,38)$ & $1(0,4)$ & $2(0,5)$ & $4(0,6)$ & $20(10,28)$ \\
\hline & & $\mathrm{p}_{1}<0.001$ & $\mathrm{p}_{1}<0.001, \mathrm{p}_{2}=0.494$ & $\mathrm{p}_{1}<0.001, \mathrm{p}_{2}=0.089$ & $\mathrm{p}_{1}=0.820, \mathrm{p}_{2}<0.001$ \\
\hline \multirow[t]{2}{*}{ Looking into the "holes" } & $7(4,10)$ & $3(1,4)$ & $3(2,4)$ & $4(3,4)$ & $7(5,9)$ \\
\hline & & $\mathrm{p}_{1}<0.001$ & $\mathrm{p}_{1}=0.001, \mathrm{p}_{2}=0.678$ & $\mathrm{p}_{1}=0.004, \mathrm{p}_{2}=0.206$ & $\mathrm{p}_{1}=0.507, \mathrm{p}_{2}<0.001$ \\
\hline
\end{tabular}

$\mathrm{p}_{1}$ - comparing with check group; $\mathrm{p}_{2}$ - comparing with the group of the animals under the hypokinetic stress.

Data presented as median, lower and upper quartiles $\left(Q_{1}, Q_{3}\right)$.

Table 2. Efficiency of the THz-band on MASO of $150.176-150.664 \mathrm{GHz}$ nitrogen oxide occurrence on indices in behavioral reactions changed by the hypokinetic stress at white male-rats (in the "Elevated plus maze" method)

\begin{tabular}{|c|c|c|c|c|c|}
\hline \multirow{2}{*}{ Indices $\quad$ Groups } & \multirow{2}{*}{$\begin{array}{l}\text { Check } \\
(n=15)\end{array}$} & \multirow{2}{*}{$\begin{array}{l}\text { Hypokinetic stress } \\
\qquad(n=15)\end{array}$} & \multicolumn{3}{|c|}{ Stress combined with persistent irradiation $(n=15)$} \\
\hline & & & 5 minutes & 15 minutes & 30 minutes \\
\hline The number of the & $5(3,6)$ & $1(0,2)$ & $1(1,2)$ & $3(1,4)$ & $4(3,5)$ \\
\hline $\begin{array}{l}\text { central platform } \\
\text { crossings }\end{array}$ & & $\mathrm{p}_{1}<0.001$ & $\mathrm{p}_{1}<0.001, \mathrm{p}_{2}=0.787$ & $\mathrm{p}_{1}=0.004, \mathrm{p}_{2}=0.125$ & $\mathrm{p}_{1}=0.852, \mathrm{p}_{2}<0.001$ \\
\hline Walking in to the open & $3(2,4)$ & $1(0,2)$ & $1(0,1)$ & $2(1,3)$ & $3(2,4)$ \\
\hline tubes & & $p_{1}<0.001$ & $\mathrm{p}_{1}<0.001, \mathrm{p}_{2}=0.229$ & $\mathrm{p}_{1}<0.001, \mathrm{p}_{2}=0.709$ & $p_{1}=0.206, p_{2}<0.001$ \\
\hline Standing upright & $7(3,11)$ & $1(0,2)$ & $1(0,1)$ & $5(3,7)$ & $6(3,9)$ \\
\hline & & $p_{1}<0.001$ & $\mathrm{p}_{1}<0.001, \mathrm{p}_{2}=0.468$ & $\mathrm{p}_{1}=1.161, \mathrm{p}_{2}=0.001$ & $\mathrm{p}_{1}=0.901, \mathrm{p}_{2}<0.001$ \\
\hline Looking down out of the & $13(5,16)$ & $1(0,1)$ & $1(0,1)$ & $7(1,8)$ & $12(5,16)$ \\
\hline $\begin{array}{l}\text { ends of the opened } \\
\text { tubes }\end{array}$ & & $\mathrm{p}_{1}<0.001$ & $\mathrm{p}_{1}<0.001, \mathrm{p}_{2}=0.534$ & $\mathrm{p}_{1}<0.001, \mathrm{p}_{2}=0.820$ & $\mathrm{p}_{1}=0.803, \mathrm{p}_{2}<0.001$ \\
\hline The number of the & $0(0,1)$ & $1(1,2)$ & $1(0,1)$ & $1(0,1)$ & $0(0,1)$ \\
\hline defecations & & $\mathrm{p}_{1}<0.001$ & $p_{1}=0.361, p_{2}=0.011$ & $\mathrm{p}_{1}=1.000, \mathrm{p}_{2}<0.001$ & $\mathrm{p}_{1}=0.756, \mathrm{p}_{2}<0.001$ \\
\hline
\end{tabular}

$\mathrm{p}_{1}-$ comparing with check group; $\mathrm{p}_{2}$ - comparing with the group of the animals under the hypokinetic stress.

Table 3. Efficiency of the THz-band on MASO of 150.176-150.664 GHz nitrogen oxide occurrence on indices in behavioral reactions changed by the hypokinetic stress at white male-rats (in the "Dark-light camera" method)

\begin{tabular}{|c|c|c|c|c|c|}
\hline \multirow{2}{*}{ Indices $\quad$ Groups } & \multirow{2}{*}{$\begin{array}{l}\text { Check } \\
(n=15)\end{array}$} & \multirow{2}{*}{$\begin{array}{l}\text { Hypokinetic stress } \\
\qquad(n=15)\end{array}$} & \multicolumn{3}{|c|}{ Stress combined with persistent irradiation $(n=15)$} \\
\hline & & & 5 minutes & 15 minutes & 30 minutes \\
\hline Looking out of the dark & $5(4,6)$ & $2(2,3)$ & $2(2,3)$ & $3(2,3)$ & $5(4,6)$ \\
\hline box & & $\mathrm{p}_{1}<0.001$ & $p_{1}<0.001, p_{2}=0.694$ & $\mathrm{p}_{1}<0.001, \mathrm{p}_{2}=0.085$ & $p_{1}=0.724, p_{2}<0.001$ \\
\hline Looking out of the dark & $33(25,39)$ & $16(10,22)$ & $17(11,23)$ & $18(12,24)$ & $33(25,42)$ \\
\hline $\begin{array}{l}\text { box (total time in } \\
\text { seconds) }\end{array}$ & & $\mathrm{p}_{1}<0.001$ & $\mathrm{p}_{1}<0.001, \mathrm{p}_{2}=0.694$ & $\mathrm{p}_{1}=0.001, \mathrm{p}_{2}=0.431$ & $\mathrm{p}_{1}=0.772, \mathrm{p}_{2}<0.001$ \\
\hline Walking out of the dark & $2(1,2)$ & $1(0,1)$ & $1(0,1)$ & $1(0,1)$ & $2(1,3)$ \\
\hline box...... & & $p_{1}<0.001$ & $p_{1}=0.003, p_{2}=0.590$ & $p_{1}=0.020, p_{2}=0.213$ & $p_{1}=0.419, p_{2}<0.001$ \\
\hline Walking out of the dark & $21(4,40)$ & $6(0,13)$ & $6(0,13)$ & $7(0,12)$ & $18(11,22)$ \\
\hline $\begin{array}{l}\text { box (total time in } \\
\text { seconds) }\end{array}$ & & $\mathrm{p}_{1}=0.015$ & $\mathrm{p}_{1}=0.025, \mathrm{p}_{2}=0.803$ & $\mathrm{p}_{1}=0.097, \mathrm{p}_{2}=0.575$ & $\mathrm{p}_{1}=0.395, \mathrm{p}_{2}<0.001$ \\
\hline The number of & $0(0,1)$ & $1(1,2)$ & $1(1,2)$ & $1(0,2)$ & $0(0,1)$ \\
\hline defecation acts & & $\mathrm{p}_{1}=0.011$ & $\mathrm{p}_{1}=0.012, \mathrm{p}_{2}=0.917$ & $\mathrm{p}_{1}=0.120, \mathrm{p}_{2}=0.290$ & $p_{1}=0.950, p_{2}=0.005$ \\
\hline
\end{tabular}

$\mathrm{p}_{1}-$ comparing with check group; $\mathrm{p}_{2}$ - comparing with the group of the animals under the hypokinetic stress.

\section{Reference}

1. Pshennikova MG. The stress phenomenon. Patological fisiology 2001; (1): 26-30. [Article in Russian]

2. Motylyanskaya RE, Kaplan EYe, Velitchenko VK, Artamonov VN. Motor activity is an important condition for a healthy lifestyle. Physical education theory and practice 1990; (1): 14-18. [Article in Russian]

3. Smirnov KV. Pishchevareniye i gipokinesiya [Digestion and hypokinesia]. Medicine, Moscow, 1990. [Text in Russian]
4. Kirichuk VF, Golovacheva TV, Parshina SS, et.al. Application of NOtherapy in Clinical Practice. Millimetrovye Volny v Biologii i Meditsyne (Millimeter Waves in Biology and Medicine) 2009; (1-2): 5-21. [Article in Russian].

5. Malyshev IU, Manukhina EB. Stress, Adaptation, and Nitric Oxide. Biochemistry 1998; 63(7): 992 - 1006. [Article in Russian]

6. Betsky OV, Lebedeva NN. Application of Low-Intensive Millimeter Waves in Biology and Medicine. Biomeditsynksaya radioelectronika (Biomedical Radioelectronics) 2007; (8-9): 6-25. [Article in Russian]. 
7. Kirichuk VF. Physiological Effects of Extremely High-Frequency and Terahertz Electromagnetic Waves: The Discoveries of Saratov Medical Scientists. Biomeditsynksaya radioelectronika (Biomedical Radioelectronics) 2007; (2-4): 98-126. [Article in Russian]

8. Kirichuk VF. Achievements of Saratov Scientists in Studying the Influence of Extremely High-Frequency and Terahertz Electromagnetic Waves on Humans and Animals. Millimetrovye Volny $v$ Biologii $i$ Meditsyne (Millimeter Waves in Biology and Medicine) 2007; (3): 5-71. [Article in Russian]

9. Kirichuk VF. Results and Perspectives of Experimental Validation of Application of Terahertz Electromagnetic Waves with Frequencies Equal to Frequencies of Molecular Absorption and Emission Spectra (MAES) of Various Cell Metabolites in Clinical Practice. Millimetrovye Volny $v$ Biologii i Meditsyne (Millimeter Waves in Biology and Medicine) 2012; (1): 5-24. [Article in Russian]

10. Kirichuk VF, Sukhova CV, Antipova ON. Influence of Exposure to Terahertz Electromagnetic Waves with Frequencies Equal to Absorption and Emission Frequencies of Atmospheric Oxygen on Functional Activity of Platelets of Albino Rats with Immobilization Stress. Biomeditsynksaya radioelectronika (Biomedical Radioelectronics) 2008; (12): 41-48. [Article in Russian]

11. Kirichuk VF, Ivanov AN, Antipova ON, Krenitskii AP, Maiborodin AV, Tupikin VD, Betskii OV. Electromagnetic irradiation of the terahertz diapason at nitric oxide frequencies for correction and prevention of disturbances of platelet functional activity in white rats during longterm stress. Cell and Tissue Biology 2007; 1(4): 357-363. (doi: 10.1134/S1990519X07040086)

12. Kirichuk VF, Tsymbal AA, Krenitsky AP, et al. Application of Terahertz Electromagnetic Waves with $129.0 \mathrm{GHz}$ Frequency of Atmospheric Oxygen for Blood Clotting and Fibrinolytic Disorder Treatment. Biomeditsynksaya radioelectronika (Biomedical Radioelectronics) 2009; (9): 11-16. [Article in Russian]

13. Tsymbal AA, Kirichuk VF. Changes gas and electrolyte structure of blood under influence terahertz radiations on frequencies nitrogen oxide 150,176-150,664 GHz in the conditions of stress. Patol Fiziol Eksp Ter 2011; (1): 49-51. (PMID: 21688667)

14. Kirichuk VF, Tsymbal AA. Effects of terahertz irradiation at nitric oxide frequencies on intensity of lipoperoxidation and antioxidant properties of the blood under stress conditions. Bull Exp Biol Med 2009; 148(2): 200-203. (PMID: 20027328)

15. Kirichuk VF, Tsymbal AA. Use of Terahertz Irradiation at the Frequencies of Nitric Oxide for Correction of the Antioxidant Properties of the Blood and Lipid Peroxidation in Stress. Neuroscience and Behavioral Physiology 2011; 41(5): 495-499. (doi: 10.1007/s11055-011-9443-4)

16. Kirichuk VF, Tsymbal AA. Use of terahertz electromagnetic radiation at nitric oxide frequencies for the correction of thyroid functional state during stress. Vestn Ross Akad Med Nauk (Annals of the Russian Academy of Medical Sciences) 2010; (4): 37-40. (PMID: 20540354)

17. Tsymbal AA, Kirichuk VF, Krenitsky AP. Recovery of Primary Indices of Metabolic Status by Exposure to Terahertz Electromagnetic Waves with Frequencies of Nitrogen Oxide $(150.176-150.64 \mathrm{GHz})$ as a Result of Expirement. Biomeditsynksaya radioelectronika (Biomedical Radioelectronics) 2011; (1): 30-35. [Article in Russian]

18. Tsymbal AA, Kirichuk VF, Antipova ON. Changes of Concentration of Adrenocorticotropic Hormone in Blood of Experimental Animals as a Result of Exposure to Terahertz Electromagnetic Waves with 129.0 $\mathrm{GHz}$ Frequency of Atmospheric Oxygen During Acute and Continuous Stress. Biomeditsynksaya radioelectronika (Biomedical Radioelectronics) 2011; (8): 23-29. [Article in Russian]

19. Kirichuk VF, Ivanov AN, Andronov EV. Influence of Terahertz Electromagnetic Waves with Frequencies of Nitrogen Oxide on Post Stress Disorders of Carbohydrate Component and Activity of Platelet Glycoprotein Receptors. Biomeditsynksaya radioelectronika (Biomedical Radioelectronics) 2010; (5): 39-46. [Article in Russian]

20. Kirichuk VF, Ivanov AN, Kiriyazi TS. Changes in Functional State of Endothelium and Peripheral Perfusion of Albino Rats with Acute
Immobilization Stress as a Result of Exposure to Terahertz Electromagnetic Waves with Frequencies of Nitrogen Oxide. Biomeditsynksaya radioelectronika (Biomedical Radioelectronics) 2010; (12): 30-37. [Article in Russian]

21. Kirichuk VF, Ivanov AN, Kirijazi TS. Correction of Microcirculatory Disturbances with Terahertz Electromagnetic Radiation at Nitric Oxide Frequencies in Albino Rats under Conditions of Acute Stress. Bulletin of Experimental Biology and Medicine 2011; 151(3): 288-291. (doi: 10.1007/s10517-011-1311-2)

22. Chuyan EN, Gornaya OI. The change of animal's motor activity with different types of motor asymmetry under the conditions of hypokinesia. Physics of living 2009; 17(2): 193-198. [Article in Russian]

23. Betsky OV, Krenitsky AP, Mayborodin AV, Kirichuk VF. Utility patent: Apparatus for the treatment of electromagnetic waves of extremely high frequency. Russian patent No.50835, 2006.

Authors:

Vyacheslav F. Kirichuk - MD, D.Sc. Professor, Honored Scientist of Russia, Head of Department of Normal Physiology n.a. I.A. Chuevsky, Saratov State Medical University n.a. V.I. Razumovsky, Saratov, Russia;

Olga N. Antipova - MD, D.Sc., Professor, Department of Normal Physiology n.a. I.A. Chuevsky, Saratov State Medical University n.a. V.I. Razumovsky, Saratov, Russia;

Jana A. Krylova - MD, Assistant, Department of Normal Physiology n.a. I.A. Chuevsky, Saratov State Medical University n.a. V.I. Razumovsky, Saratov, Russia;

Evgeny V. Andronov - MD, D.Sc., Professor, Department of Normal Physiology n.a. I.A. Chuevsky, Saratov State Medical University n.a. V.I. Razumovsky, Saratov, Russia. 